\title{
EVALUATION OF THE GROWTH AND SURVIVAL OF MANGROVE SEEDLINGS UNDER DIFFERENT LIGHT INTENSITIES: SIMULATING THE EFFECT OF MANGROVE DEFORESTATION
}

\author{
Neilson Rocha da Silva ${ }^{2 *}$, Rafaela Camargo Maia $^{3} \cdot$
}

\begin{abstract}
${ }^{1}$ Received on 25.03.2019 accepted for publication on 05.09.2019.
${ }^{2}$ Instituto Federal do Ceará, Programa de Pós-Graduação em Ecologia e Recursos Naturais, Fortaleza, CE - Brasil. E-mail: < neilsonrocha@ outlook.com.br>.

${ }_{3}^{3}$ Instituto Federal do Ceará, Campus Acaraú, Acaraú, CE- Brasil E-mail: <rafaelacmaia@yahoo.com.br>.

*Corresponding author.
\end{abstract}

\begin{abstract}
Environmental factors, especially light, temperature, and edaphic conditions are of great importance for the establishment of plant communities. In areas degraded by deforestation, these factors can vary greatly, which may affect the recolonization of the typical populations in the altered area. This study evaluated the development of seedlings of pioneer mangrove species under different levels of shading in soil substrate degraded by deforestation, aiming to assess the effect of deforestation on the recolonization of mangrove forests, which may be of help in the production of seedlings and recovery of deforested areas. The study was conducted in the municipality of Acaraú in the state of Ceará, Brazil. The species Avicennia schaueriana Stapf and Leechm. ex Moldenke (1939) and Laguncularia racemosa C. F. Gaertn (1807) were used in the study, and the substrate was collected from an area impacted by deforestation. The propagules and seedlings were exposed to full sun and 30,50 and $70 \%$ shading. The results revealed that the treatment at full sun had the lowest germination rate of $86.66 \%$ for L. racemosa. Seedlings of both species showed a significant difference and better quality between shading treatments and full sun. The height of the seedlings showed a correlation above -0.90 with ambient temperature. L. racemosa tested in full sun had a viable seedling reduction of $50 \%$ and $A$. schaueriana was superior. It is concluded that the natural regeneration of a mangrove area can be compromised under the conditions of total deforestation with high sun exposure and degraded soils. Human intervention in providing $50 \%$ shading is essential for the development of seedlings and regeneration of the area impacted by deforestation.
\end{abstract}

Keywords: Mangrove recovery; Seedling production; Plant development.

\section{AVALIAÇÃO DO CRESCIMENTO E SOBREVIVÊNCIA DE PLÂNTULAS DE MANGUE SOB DIFERENTES INTENSIDADES LUMINOSAS: SIMULANDO O EFEITO DO DESMATAMENTO DOS MANGUEZAIS}

\begin{abstract}
RESUMO - - Os fatores ambientais, principalmente a luminosidade, temperatura e as condições edáficas são de grande importância para o estabelecimento da comunidade vegetal. Em áreas degradadas por desmatamento, esses fatores podem passar por alterações de grande magnitude, podendo a fetar a recolonização das populações típicas da área alterada. Neste contexto, o objetivo deste estudo foi avaliar o desenvolvimento de plântulas de espécies pioneiras de mangue sob diferentes níveis de sombreamento, em substrato de solo degradado pelo desmatamento, visando o efeito do desmatamento na recolonização das plântulas de mangue e gerar subsidios para a recuperação de áreas desmatadas e produção de mudas. O estudo foi realizado no Instituto Federal do Ceará, localizado no Município de Acaraú no Estado do Ceará, Brasil. Para o experimento foram escolhidas as espécies Avicennia schaueriana Stapf and Leechm. ex Moldenke (1939) e Laguncularia racemosa C. F. Gaertn (1807). O substrato para produção das mudas foi coletado em área impactada por desmatamento, apresentando baixa fertilidade e de textura franco argilosa. As plântulas foram testadas a
\end{abstract}

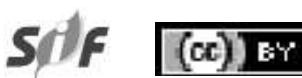

Revista Árvore 2019;43(3):e430308 http://dx.doi.org/10.1590/1806-90882019000300008 


\begin{abstract}
pleno sol e sob niveis de 30\%, 50\% e 70\% de sombreamento. Os dados obtidos foram altura, diametro do coleto, anotações das condições fenológicas das plântulas, matéria fresca, matéria seca da raiz, parte aérea e a temperatura ambiente dos viveiros. Os resultados revelaram que em condições de desmatamento total da área de mangue, gerando alta luminosidade e solos degradados, a regeneração natural é comprometida, sendo essencial a intervenção humana, com sombreamento de 50\% para uma boa estabilidade de plântulas.
\end{abstract}

Palavras-Chave: Recuperação de manguezais; produção de mudas; desenvolvimento de plantas.

\section{INTRODUCTION}

Mangroves are ecosystems established in coastal areas with average temperatures above $16^{\circ} \mathrm{C}$, brackish water, unconsolidated soil, and characterized by interactions between soil, freshwater and seawater (Saenger, 2002; Tomlinson, 2016; Duke, 2017). The mangrove forest is a component of great importance to the mangrove ecosystem, providing essential resources for the survival of numerous species, including humans, besides promoting the control of hydrodynamics and erosion, protecting against storms, and stabilizing climatic conditions along the coastline (Alongi, 2008; Lee et al., 2014).

Mangrove forests in the state of Ceará are composed of four plant species, namely Avicennia germinans L. (Stearn 1958), A. schaueriana, Laguncularia racemosa, and Rhizophora mangle L. (1753), while another species, Conocarpus erectus $\mathrm{L}$ (1753), occupies higher ground and receives low tidal influence (Camargo Maia and Coutinho, 2012; Vale and Schaeffer-Novelli, 2018). Anthropogenic changes in the environment have a strong impact on this area, such as the deforestation of mangroves for firewood and charcoal, residential construction, making fishing artifacts, and various developments (Maia et al., 2018).

The canopy of mangrove forests can present a wide variety of sunflecks, depending on the plant species, arrangement of canopies, and conservation of the mangrove ecosystem (Asaeda et al., 2016). Sunflecks are small spaces in the canopy structure of a forest where the light passes through. Therefore, they are essential for the germination and growth of propagules, seedlings, and juvenile plants in the soil of mangroves (Maciel et al., 2002). Intense changes in this environment, such as deforestation, will result in a great increase in light as reported by Querino et al.
(2013), albedo elevation of $49 \%$, fertility decline, and soil destruction and loss (Arruda, 2013).

These changes affect mangrove seedlings, influencing their establishment, early development and resilience (Clarke, 2004; Krauss et al., 2008; Balke et al., 2015). The adaptation of plant species to new environmental conditions, particularly light, is especially important in juvenile plants because it conditions morphogenetic and physiological alterations in their structure and function, determining the success of regeneration (Pérez et al., 2017).

In the case of mangrove forest species, studies addressing issues such as seedling development under different shading levels and recolonization of clearings are scarce. Hence, this study evaluated the development of seedlings of pioneer mangrove species under different levels of shading in soil substrate degraded by deforestation, aiming to assess the effect of deforestation on the recolonization of mangrove seedlings and generate subsidies for the recovery of deforested areas and production of seedlings.

\section{MATERIAL AND METHODS}

\subsection{Study area}

The study was carried out at the Federal Institute of Ceará - Acaraú Campus (-2.889037 ${ }^{\circ} \mathrm{S}$ and $-40.113054^{\circ} \mathrm{W}$ ) located in the Municipality of Acaraú in the State of Ceará, Northeastern Brazil. According to the aridity index (AI) from several rainfall stations in the state of Ceará (Funceme, 2017), the municipality shows a sub-humid type of regional climate $(65 \leq \mathrm{AI}<100)$. Data from the National Institute of Meteorology (INMET) (Lima Junior et al., 2016) showed a mean annual temperature of $27.6{ }^{\circ} \mathrm{C}$, relative humidity $(\mathrm{RH})$ of $80.73 \%$, and wind speed of $4.2 \mathrm{~m} / \mathrm{s}$ in the period of 1976 to 2011. 


\subsection{Choice of species and procedures with propagules, substrate and irrigation}

The species $A$. schaueriana and L. racemosa were chosen because they are pioneer mangrove species (Costa et al., 2014). Propagules were collected near the Curral Velho village in the municipality of Acaraú - CE $\left(-2.889037^{\circ} \mathrm{S}\right.$ and $\left.-40.077642^{\circ} \mathrm{W}\right)$, according to Silva and Maia (2018). The propagules were collected by manual harvesting, found on the soil, and they were viable and non-germinated. Propagules were visually sorted for apparent health and size in the laboratory to select propagules with similar characteristics. Propagules were subsequently washed in running water, immersed in $1 \%$ sodium hypochlorite $(\mathrm{NaClO})$ for $5 \mathrm{~min}$ for disinfection, and washed again in running water according to Silva and Maia (2018).

The substrate for seedling production was collected between zero and $20 \mathrm{~cm}$ deep in the first layer of soil and $15 \mathrm{~m}$ from the riverbank in an area impacted by deforestation $\left(-2.876921^{\circ} \mathrm{S}\right.$ and $-40.126909^{\circ} \mathrm{W}$ ), because most environmental factors undergo modifications in deforested areas (Arruda, 2013). This collection method was chosen to avoid the soils of the riverbank where nutrient concentration is maintained in the system, mainly due to the mixing of fresh water with salt water (Baran and Hambrey 1998; Alves, 2001).

The substrate was sun-dried, fragmented into small-sized clumps and homogenized, ensuring greater uniformity. Afterwards, the propagules were sown and irrigated using the public water supply. The seedlings were irrigated with $40 \mathrm{ml} /$ plant on average in each treatment, twice a day, at 8 am and $5 \mathrm{pm}$.

\subsection{Time of experiment, design, evaluation, and data collection}

The study was carried out from May to July of 2017 (60 days), ending when the development of the seedlings was considered completed. The beginning of the juvenile phase, on average 60 days after sowing, is recognized by the loss of the cotyledons (embryonic leaves) in L. racemosa and A. racemosa and by the formation of adult-like leaves representing the end of the supply of compounds from the embryonic (Oliveira, 2017).
We used a 2 x 4 x 3 factorial completely randomized design (two species, four levels of shading, and three replications). Each treatment contained ten seedlings of each species, totaling 240 seedlings (10 seedlings $\times 2$ species $\times 4$ treatments $\times 3$ replicates). The seedlings were exposed to full sunshine $(0 \%$ shading) and levels of 30, 50 and $70 \%$ shading using polyethylene screens. The seedlings were monitored daily, and data on plant structure and germination percentage were collected every eight days after the stems were completely erect and showed the first pair of leaves in A. schaueriana and L. racemosa.

The structural data collected were height, rootcollar diameter (RCD), and phenological conditions of seedlings (coloration and number of leaves and branches). A graduated ruler was used to measure height, and an analog caliper with an accuracy of $0.005 \mathrm{~mm}$ was used to measure the RCD.

The Dickson quality index (DQI) (Dickson et al., 1960) was used to obtain structural height $(\mathrm{H})$ and RCD data using nine randomly collected seedlings of each species (three seedlings per replicate per treatment). Subsequently, the aerial part of the root system was separated and dehydrated at $60{ }^{\circ} \mathrm{C}$ for 20 $\mathrm{h}$ in a drying oven to obtain root, shoot, and total dry matter. A precision balance (SHIMADZU AY220), with a precision of $0.0001 \mathrm{~g}$, was used to weigh fresh matter and root and shoot dry matter. The following formula was used to calculate the quality index: DQI $=($ total dry matter $) /((\mathrm{H}+\mathrm{RCD}+$ aerial dry matter $) /$ (root dry matter))).

For the analysis of total dry matter and water content of the seedling (total fresh matter minus total dry matter) the data obtained for DQI were used. The temperature of the experimental units was measured using a mercury thermometer placed for seven minutes in each experimental unit during the hottest period of the day, between 2 and 4 pm; these data were collected twice a month.

\subsection{Statistical analysis}

Descriptive analysis was performed on the following parameters: number of viable plants, percentage of germination, and physiological and phenological characteristics. Two-way ANOVA was used (species and treatment) to evaluate the height, $\mathrm{RCD}$, dry matter and water content data. One-way 
ANOVA was performed to analyze the variation in RCD during the experimental time. Tukey's test was used to compare results when differences between treatments were observed at a 95\% confidence interval. Linear correlation analysis was conducted to verify the correlation between shading percent and germination rate, height, and temperature in the experimental units. Pearson's correlation was used in three sample pairs with 12,000 simulations at a $95 \%$ confidence interval, resulting in the r correlation.

\section{RESULTS}

The results showed that germination rates were good for both species tested (Table 1). A. schaueriana had rates above $90 \%$ and the treatments with 50 and $0 \%$ shading reached $100 \%$ germination; however, $0 \%$ shading did not maintain $100 \%$ of seedlings during the experiment time. We also found that the higher the level of shading the better the germination rate in the first week; thus, better germination rates were achieved with greater shading, with a positive Pearson correlation of $\mathrm{r}=0.9852$. On the other hand, the propagules of $L$. racemosa in the treatment with $50 \%$ shading had a $100 \%$ germination rate and the treatment in full sun $(0 \%$ shading) produced the lowest germination rate.

All treatments with shading showed a significant difference in height compared to $0 \%$ shading for $L$. racemosa $(\mathrm{F} 3,99=23.984, \mathrm{p}=0.00001)$ (Figure 1). The seedlings with 50 and $70 \%$ shading differed significantly from those with $30 \%$ shading, but there was no difference between the two higher shading levels. A. schaueriana seedlings in the 50 and $70 \%$ shading treatments differed significantly in height from those produced at $0 \%$ shading, but did not differ from those with $30 \%$ shading $(\mathrm{F} 3,109=6.3428, \mathrm{p}=$ 0.00053).

The $L$. racemosa species was significantly different in the 30 and $50 \%$ shade treatments, with the largest RCD (F 3, $99=9.0339, \mathrm{p}=0.00002)$ (Figure 2). A. schaueriana showed no significant difference between shading treatments, the mean RCD was $3.4296 \mathrm{~mm}$ for full sun, $3.6893 \mathrm{~mm}$ for $30 \%$ shading, $3.6800 \mathrm{~mm}$ for $50 \%$ shading and $3.4000 \mathrm{~mm}$ for $70 \%$ shading, proving to be a species with good adaptability variation in light.

The $50 \%$ shading treatment provided greater accumulation of dry matter in L. racemosa seedlings, differing significantly from those with full sun exposure (F 3, $32=4.6811, \mathrm{p}=0.00804)$. The means obtained were $0.5732 \mathrm{~g}$ with full sun, $0.7977 \mathrm{~g}$ with $30 \%$ shading, $0.9110 \mathrm{~g}$ with $50 \%$ shading, and $0.6626 \mathrm{~g}$ with $70 \%$ shading. L. racemosa seedlings produced under $50 \%$ shading also showed the highest water content with $4.7411 \mathrm{~g}$, followed by seedlings with $30 \%$ shading $(3.5389 \mathrm{~g}), 70 \%$ shading $(3.0100$ $\mathrm{g})$, and full sun exposure $(2.3411 \mathrm{~g})$. The seedlings treated with $50 \%$ shading differed significantly from those produced in full sun and 70\% shading (F 3, $32=$ $8.7120, \mathrm{p}=0.00023$ ) (Figure 2).

A. schaueriana seedlings showed no significant difference in total dry matter gain; however, seedlings grown under $50 \%$ shading showed the highest mean of $0.9897 \mathrm{~g}$ for dry matter gain, followed by $30 \%$ shading with $0.9554 \mathrm{~g}, 70 \%$ shading with $0.8372 \mathrm{~g}$, and full sun exposure with $0.7674 \mathrm{~g}$. A. schaueriana seedlings also showed no significant difference in water content between treatments. The seedlings showed the following amounts of water content: full

Table 1 - Germination rates of Avicennia schaueriana seedlings during the experimental weeks (1 to 7) and under different shading treatments $(0,30,50$, and $70 \%)$.

Tabela 1 - Taxa de plântulas das espécies Avicennia shaueriana e Laguncularia racemosa por semanas experimentais (1 a 7 ) nos tratamentos de sombreamento $(0 \%, 30 \%, 50 \%$ e $70 \%)$.

\begin{tabular}{|c|c|c|c|c|c|c|c|c|c|}
\hline \multicolumn{5}{|c|}{ Avicennia schaueriana } & \multicolumn{5}{|c|}{ Laguncularia racemosa } \\
\hline \multirow[t]{2}{*}{ Weeks } & \multicolumn{4}{|c|}{ Treatments } & \multirow[t]{2}{*}{ Weeks } & \multicolumn{4}{|c|}{ Treatments } \\
\hline & $0 \%$ & $30 \%$ & $50 \%$ & $70 \%$ & & $0 \%$ & $30 \%$ & $50 \%$ & $70 \%$ \\
\hline 1 & 50,00 & 60,00 & 73,33 & 86,66 & 1 & 23,33 & 56,66 & 44,33 & 56,66 \\
\hline 2 & 80,00 & 96,66 & 100 & 93,33 & 2 & 66,66 & 56,66 & 100 & 96,66 \\
\hline 3 & 93,33 & 96,66 & 100 & 90,00 & 3 & 70,00 & 96,66 & 100 & 96,66 \\
\hline 4 & 93,33 & 96,66 & 100 & 93,33 & 4 & 70,00 & 93,33 & 100 & 96,66 \\
\hline 5 & 100 & 93,33 & 100 & 90,00 & 5 & 86,66 & 83,33 & 100 & 96,66 \\
\hline 6 & 90,00 & 93,33 & 100 & 93,33 & 6 & 66,66 & 93,33 & 96,66 & 90,00 \\
\hline 7 & 90,00 & 93,33 & 100 & 93,33 & 7 & 66,66 & 93,33 & 93,33 & 90,00 \\
\hline
\end{tabular}

Revista Árvore 2019;43(3):e430308 

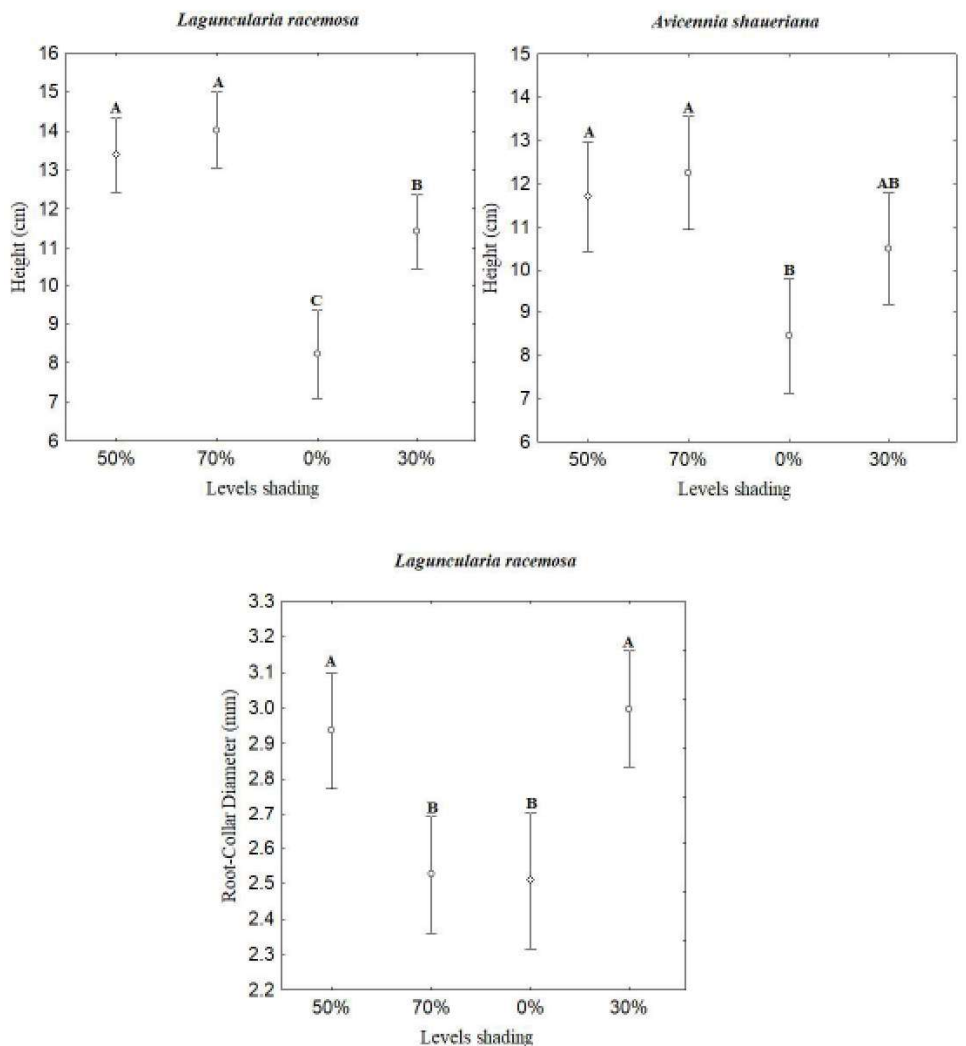

Figure 1 - Height and Collar diameter, average + standard error between different shading levels $(0 \%, 30 \%, 50 \%$, and $70 \%)$ in seedlings of Laguncularia racemosa and Avicennia schaueriana. Different letters indicate significant differences according to the Tukey's Test.

Figura 1 - Altura e diâmetro do colar, média + erro padrão entre diferentes níveis de sombreamento $(0 \%, 30 \%, 50 \%$ e $70 \%)$ em mudas de Laguncularia racemosa e Avicennia schaueriana. Letras diferentes indicam diferenças significativas de acordo com o teste de Tukey.

sun exposure, $2.9767 \mathrm{~g} ; 30 \%$ shading, $3.8967 \mathrm{~g} ; 50 \%$ shading, $3.8589 \mathrm{~g}$; and $70 \%$ shading, $3.3800 \mathrm{~g}$.

In relation to the nursery temperature and seedling height, linear correlation analysis showed that the lower the ambient temperature, the greater growth was for both study species with -0.981 for $L$. racemosa and -0.984 for $A$. schaueriana. The best DQI was obtained in seedlings in the $50 \%$ shading treatment for both species. The lowest indices were obtained in full sun and $70 \%$ shading treatments (Table 2).

Through the monitoring of the structure of the seedlings it was possible to observe branching development. L. racemosa had a higher percentage of branches at the $30 \%$ shading level. A. schaueriana showed a higher percentage of branches at the $50 \%$ shading level (Figure 3A). Finally, the quality of seedlings grown at different levels of shading showed some percentage of chlorinated or nongerminated seedlings, probably due to the fact that the substrate comes from degraded area soil. However, degraded soils and in full sun impacted the seedlings negatively. Therefore, both species studied had a higher percentage of chlorinated, non-germinated and dead seedlings with $0 \%$ shading treatment, where $A$. schaueriana was more affected (Figure 3B).

\section{DISCUSSION}

Germination rates were good in A schaueriana for all treatments, showing rates above $90 \%$, which may be related to nutritional reserves and the water content level in the propagules, making germination less sensitive to treatments. L. racemosa had high germination potential, except with full sun treatment ( $0 \%$ shading), which showed the lowest germination rate of $86.66 \%$. This demonstrated that in deforested 

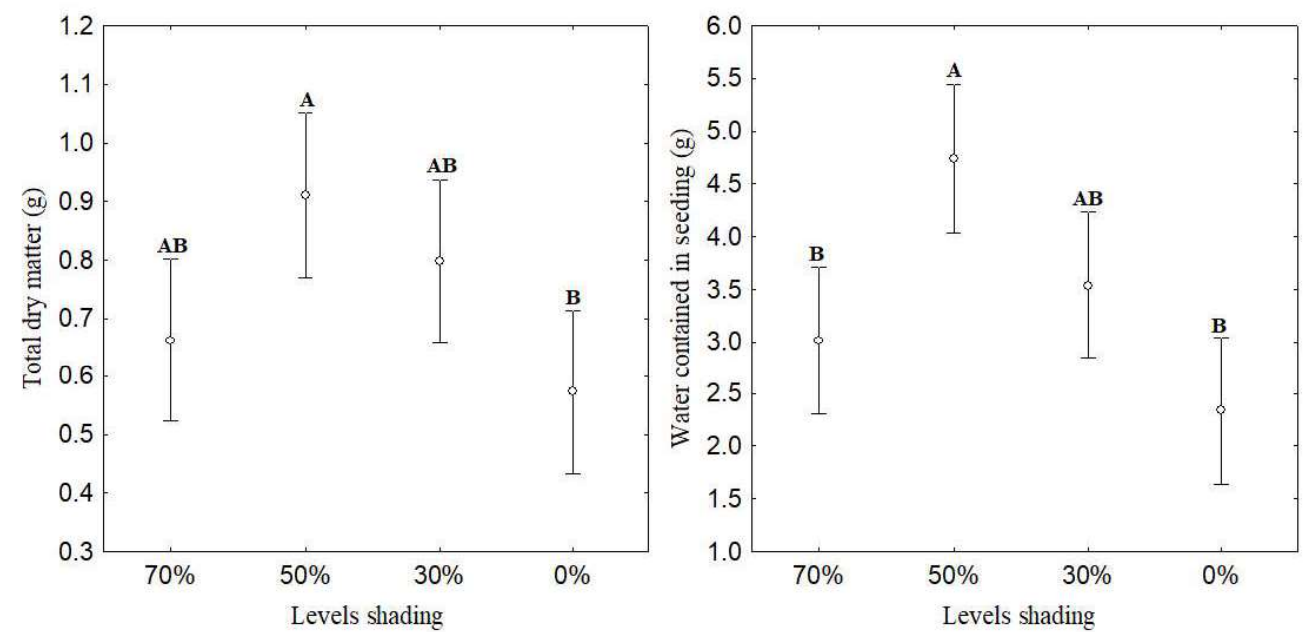

Figure 2 - Total dry matter and Water contained in the seedlings, average + standard error in Laguncularia racemosa seedlings according to different shading levels $(0 \%, 30 \%, 50 \%$, and $70 \%)$. Different letters indicate significant differences according to the Tukey's Test.

Figura 2 - Total de matéria seca e água contida nas mudas, média + erro padrão nas mudas de Laguncularia racemosa de acordo com diferentes níveis de sombreamento $(0 \%, 30 \%, 50 \%$ e $70 \%)$. Letras diferentes indicam diferenças significativas de acordo com o teste de Tukey.

Table 2 - Quality index of seedlings produced under different levels of shading.

Tabela 2 - Indice de qualidade das plântulas produzidas sob diferentes níveis de sombreamento.

\begin{tabular}{cccccccc}
\hline Species & SL & DMAP & RDM & TDM & H & RCD & IQD \\
\hline \multirow{3}{*}{ Avicennia } & $0 \%$ & 5,1626 & 1,7442 & 6,9068 & 10,8667 & 3,1915 & 0,6268 \\
schaueriana & $30 \%$ & 6,3226 & 2,2759 & 8,5985 & 11,0000 & 3,3636 & 0,9460 \\
& $50 \%$ & 6,2547 & 2,6527 & 8,9074 & 11,8542 & 3,3269 & 1,1023 \\
& $70 \%$ & 5,6726 & 1,8624 & 7,5350 & 11,4333 & 3,2388 & 0,6898 \\
\hline \multirow{2}{*}{ Laguncularia } & $0 \%$ & 3,9093 & 1,2495 & 5,1588 & 11,0714 & 3,1628 & 0,3553 \\
racemosa & $30 \%$ & 5,5344 & 1,6448 & 7,1792 & 11,1591 & 3,2439 & 0,5923 \\
& $50 \%$ & 6,1399 & 2,0594 & 8,1993 & 11,4898 & 3,2000 & 0,8107 \\
& $70 \%$ & 5,0446 & 0,9188 & 5,9634 & 11,6491 & 3,2500 & 0,2747 \\
\hline
\end{tabular}

$\mathrm{SL}=$ Shading level, $\mathrm{TDM}=$ Total Dry Matter $(\mathrm{g}), \mathrm{H}=$ Seedling height $(\mathrm{cm}), \mathrm{RCD}=$ Root Collar Diameter $(\mathrm{mm}), \mathrm{DMAP}=\mathrm{Dry}$ matter in the Aerial Part $(\mathrm{g})$, and $\mathrm{RDM}$ $=$ Root Dry Matter $(\mathrm{g})$.

NS = Nivel de sombreamento, MST = Matéria Seca Total $(\mathrm{g}), \mathrm{H}=$ Altura da plântula $(\mathrm{cm}), \mathrm{DC}=$ Diâmetro do Coleto (mm), MSPA = Matéria Seca da Parte Aérea $(\mathrm{g})$ e MSR = Matéria Seca da Raiz (g).

areas, the germination potential of L. racemosa can be reduced. Even so, these results corroborate those of other studies where germination tests with $L$. racemosa propagules resulted in a high germination rate (Silva et al., 2017; Silva and Maia, 2018).

The growth rates of $A$. schaueriana and $L$. racemosa were very similar in the treatments evaluated, with greater growth in the $70 \%$ shading treatment and lower growth in full sun exposure. Pereira et al. (2009) produced seedlings in in full sun and irrigation with fresh water, which are conditions similar to those used in the present study in the $0 \%$ shading treatment. These data reinforce the effect of direct sunlight on mangrove seedlings, reducing their size.

The seedlings of L. racemosa and $A$. schaueriana of the 50 and $70 \%$ shading treatments had the best heights, but the did not differ significantly. These results corroborate those reported by Clara and Giordano (2014) in the state of São Paulo when monitoring the development of $L$. racemosa seedlings in full sun exposure and 35,50 , and $80 \%$ shading, with the best result obtained with $50 \%$ shading. Similar results have been obtained in forest species in other ecosystems and agroecosystems (Paiva et al., 2003; Oliveira and Perez, 2012; Rezende et al., 2017).

\section{Revista Árvore 2019;43(3):e430308}




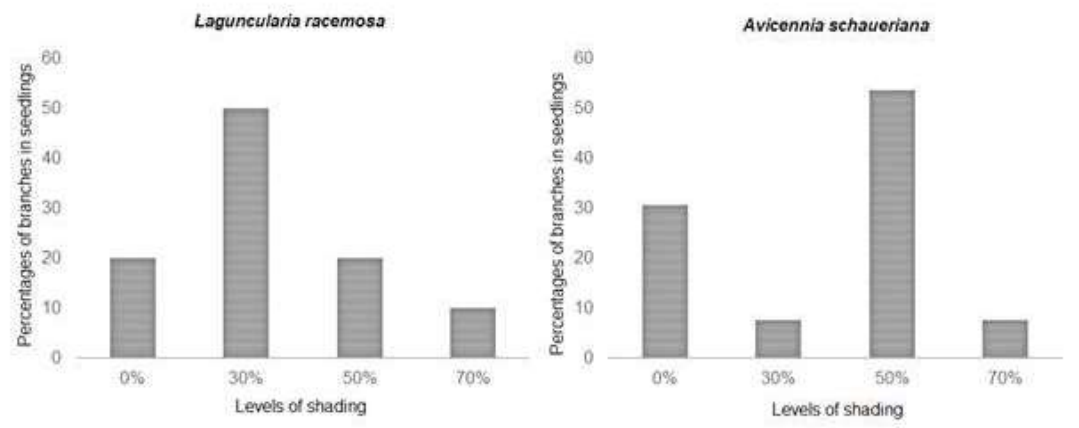

Figure 3 - A

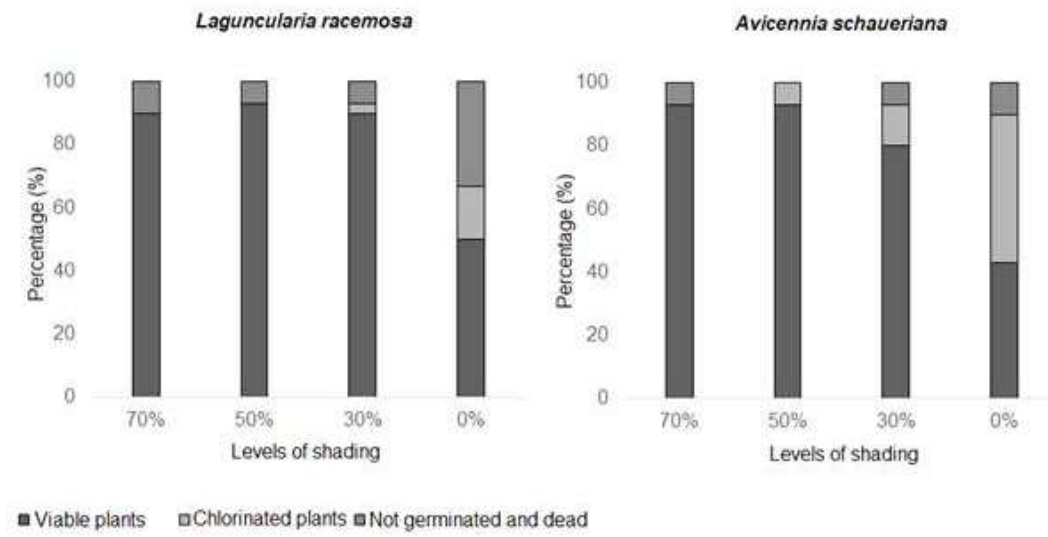

Figure 3 - A) Percentages of branches in Laguncularia racemosa and Avicennia schaueriana seedlings under different shading levels; B) Percentage representation of physiological characteristics, germination, and mortality in Laguncularia racemosa and Avicennia schaueriana seedlings at different levels of shading $(0 \%, 30 \%, 50 \%$, and $70 \%)$.

Figura $3-$ A) Porcentagens de ramificações nas espécies Laguncularia racemosa e Avicennia schaueriana por nível de sombreamento. B) Representação em porcentagem das características fisiologias, germinação e mortalidade das plântulas de Laguncularia racemosa e Avicennia schaueriana nos diferente níveis de sombreamento (0\%,30\%, 50\% e 70\%).

The 30 and $50 \%$ shading treatments provided greater environmental comfort for $L$. racemose, with a consequent increase in photosynthesis and photoassimilates in plant tissue, which significantly affected the RCD. In general, differences in light conditions may lead to variations in chlorophyll content (Brant et al., 2011) and thus reflect on biomass. The RCD of seedlings exposed to $0 \%$ shading was probably restricted by the strong sunlight and substrate drying up, which compromise photosynthesis (Pereira et al., 2015).

Dry matter analysis showed that the best growth was obtained with $50 \%$ shading. According to Paiva et al. (2003), the total amount of dry matter accumulated by a plant, as a parameter of growth evaluation, is a direct reflection of the net photosynthetic production added to the amount of absorbed mineral nutrients, reinforcing the results of Clara and Giordano (2014).

It is believed that $50 \%$ shading has a positive effect on seedling transpiration, and this may explain the higher amount of water in L. racemosa and $A$. schaueriana seedlings produced under this level of shading. Dutra et al. (2012) evaluated physiological parameters in copaíba (Copaifera langsdorffii Desf.) under the same four levels of shading used in this study and found that the $50 \%$ shading treatment provided the lowest values of daily transpiration and at time points measured throughout the day in the plants. This result may explain the greater amount of water in L. racemosa and A. schaueriana seedlings produced under $50 \%$ shading.

\section{Revista Árvore 2019;43(3):e430308}


The results also showed a significant linear correlation between the height of seedlings and ambient temperatures provided by the shading levels, so the higher the temperature (full sun) the smaller the seedling. Dalastra et al. (2012) and Costa et al. (2011) also observed greater heights in cultivars of arugula and Mimosa lettuce with increasing shading levels $(0,30,40$, and 50\%). Shading may reduce vapor pressure deficit, air and soil temperature, and wind speed, which were significantly lower in the shaded system in coffee crops compared to full sun (Lunz, 2006).

The best DQI was obtained in seedlings with the $50 \%$ shading treatment in both species. The $50 \%$ shading treatment provides seedlings with the greatest robustness and biomass balance. Although seedlings in the $70 \%$ shading treatment showed higher mean height values than those in the $30 \%$ shading for A. schaueriana and 50\% for L. racemosa, they displayed lower quality indices after $0 \%$ shading treatment. This was caused by cellular stretching, which contributes to greater heights under shade environments (King, 1994; Carvalho et al., 2006).

The development of leaves was not affected by any of the treatments in either species. A. schaueriana had three pairs of leaves and L. racemosa four pairs of leaves at the end of the experiment. Clara and Giordano (2014) followed the development of $L$. racemosa seedlings for 130 days and did not observe a significant difference in leaf gain between different shading levels. Morandi et al. (2009) performed a study with Calophyllum brasiliensis Camb. under full sun exposure and 30, 50, 70, and 90 shading and did not observe a difference in the number of leaves during the study.

Regarding lateral development, both species developed branches in all treatments. L. racemosa showed more branched individuals in the $30 \%$ shading treatment, representing $50 \%$ of the branched seedlings. A. schaueriana showed more branched individuals in the 50 and $30 \%$ shading treatments, representing respectively $53.85 \%$ and $30.77 \%$ of the branched seedlings. Thus, increased branching is not attributed to greater light intensity and solar radiation in mangrove seedlings because mangrove forest altered by deforestation showed more branched individuals of L. racemosa (Santos et al., 2012).
We found that the higher the shading, the better the seedling performance in soils degraded by deforestation. L. racemosa responded well to the 50\% shading treatment with a high rate of viable seedlings and low rate of non-germinated and dead seedlings. $A$. schaueriana seedlings exhibited a better performance in the 50 and $70 \%$ shading treatments and appeared to be more sensitive to areas degraded by deforestation, showing a low rate of viable seedlings and high rate of chlorinated, non-germinated, and dead seedlings. In summary, soils degraded by deforestation and exposed to full sunshine show decreased seedling survival rate and high rates of chlorinated individuals that lead to mortality and non-germinated and dead seedlings.

\section{CONCLUSION}

We conclude that deforestation of mangroves interferes with the recolonization of the mangrove by reducing the germination rate of $L$. racemosa species and mortality of seedlings of both species studied. $L$. racemosa seedlings exhibited higher physiological resistance in soil conditions of deforested areas under full sun. Deforested areas with high light intensity require intervention with shading, planting and replanting due to the high mortality of seedlings. 50\% shade treatment provided higher quality and stability of seedlings in deforested environments.

\section{ACKNOWLEDGEMENTS}

The authors thank the financial, structural and logistical support of the following organizations: the Pro-rectory of Research, Postgraduate and Innovation (PRPI) of the Federal Institute of Education, Science and Technology of Ceará (IFCE) by the financing through the announcement PROAPP / Postgraduate. To the National Council for Scientific and Technological Development (CNPq), for the granting of scholarship. To the IFCE and the Mangrove Ecology Laboratory (ECOMANGUE) for providing space, equipment and collaborators in the execution of this research, especially to technicians and interns / scholars.

\section{REFERENCES}

Alves JRP. Manguezais: educar para proteger. Cooperação Técnica Brasil - Alemanha, Projeto Planágua Semads-GTZ. Rio de Janeiro: FEMAR: SEMADS. 2001; [cited 2017 December 16]. 
Available: http://www.mma.gov.br/estruturas/sqa pnla/_arquivos/manguezais.pdf

Alongi DM. Mangrove forests: resilience, protection from tsunamis, and responses to global climate change. Estuarine Coastal and Shelf Science. 2008;76(1):1-13. doi: https://doi.org/10.1016/j. ecss.2007.08.024.

Arruda CPS. Monitoramento de mudas de espécies arbóreas de mangue na rodovia PA do km 17, BragançaPará. [Trabalho de Conclusão de Curso]. Campus de Bragança (PA): Universidade Federal do Pará; 2013.

Asaeda T, Barnuevo A, Sanjaya K, Fortes MD, Kanesaka Y, Wolanski E. Mangrove plantation over a limestone reef - good for the ecology? Estuarine, Coastal and Shelf Science. 2016;173:57-64. doi: https://doi.org/10.1016/j.ecss.2016.02.017.

Balke T, Swales A, Lovelock CE, Herman PMJ, Bouma TJ. Limits to seaward expansion of mangroves: translating physical disturbance mechanisms into seedling survival gradients. Journal of Experimental Marine Biology and Ecology. 2015;467:16-25. doi: https://doi.org/10.1016/j. jembe.2015.02.015.

Baran E, Hambrey J. Mangrove conservation and coastal management in southeast Asia: what impact on fishery resources? Marine Pollution Bulletin. 1999;37(8-12):431-440. doi: https://doi.org/10.1016/ S0025-326X(99)00076-4.

Bernardino AF, Gomes LEO, Hadlich HL, Andrades $\mathrm{R}$, Correa LB. Mangrove clearing impacts on macrofaunal assemblages and benthic food webs in a tropical estuary. Mar Pollut Bull. 2018;126:228-235. doi: https://doi.org/10.1016/j.marpolbul.2017.11.008.

Brant RS, Pinto JEBP, Rosal LF, Alves C, Oliveira C, Albuquerque CJB. Adaptações físiológicas e anatômicas de Melissa officinalis L. (Lamiaceae) cultivadas sob malhas termorrefletoras em diferentes intensidades luminosas. Revista Brasileira de Plantas Medicinais. 2011;13(4):467-474. doi: http:// dx.doi.org/10.1590/S1516-05722011000400012.

Brasil. Lei no 12.651 , de 25 de maio de 2012. Dispõe sobre a proteção da vegetação nativa; altera as Leis $\mathrm{n}^{\mathrm{o}} \mathrm{s}$ 6.938, de 31 de agosto de 1981, 9.393, de 19 de dezembro de 1996 , e 11.428 , de 22 de dezembro de 2006; revoga as Leis $n^{\circ} \mathrm{s} 4.771$, de 15 de setembro de 1965 , e 7.754 , de 14 de abril de 1989, e a Medida Provisória $\mathrm{n}^{\circ}$ 2.166-67, de 24 de agosto de 2001; e dá outras providências. Disponível em:

http://www.planalto.gov.br/ccivil_03/_ato20112014/2012/lei/L12651 compilado.htm

Camargo Maia R, Coutinho R. Structural characteristics of mangrove forests in Brazilian estuaries: a comparative study. Revista de Biología Marina y Oceanografía. 2012;47(1):8798. doi: http://dx.doi.org/10.4067/S071819572012000100008.

Carvalho NOS, Pelacani CR, Rodrigues MOS, Crepaldi IC. Crescimento inicial de plantas de licuri (Syagrus coronata (Mart.) Becc.) em diferentes níveis de luminosidade. Revista Árvore. 2006;30(3):351-357. doi: http://dx.doi.org/10.1590/ S0100-67622006000300005.

Clara MM, Giordano F. Acompanhamento do desenvolvimento de mudas de laguncularia racemosa cultivadas em viveiros com diferentes níveis de sombreamento. Anais do 14 Congresso Nacional de Iniciação Científica; 2014; Universidade Santa Cecília. São Paulo: Semesp/Unicid; 2014.

Clarke PJ. Effects of experimental canopy gaps on mangrove recruitment: lack of habitat partitioning may explain stand dominance. Journal of Ecology. 2004;92(2):203-213. doi: https://doi.org/10.1111/ j.0022-0477.2004.00861.x.

Costa CMF, Seabra Júnior S, Arruda GR, Souza SBS. Desempenho de cultivares de rúcula sob telas de sombreamento e campo aberto. Semina: Ciências Agrárias. 2011;32(1):93-102.

Costa DFS, Rocha RM, Cestaro LA. Análise fitoecológica e zonação de manguezal em estuário hipersalino. Mercator. 2014;13(1):119-126. doi: http://dx.doi.org/10.4215/RM2014.1301.0009.

Dalastra GM, Hachmann TL, Echer MM, Guimarães VF, Fiametti MS. Características produtivas de cultivares de alface Mimosa, conduzida sob diferentes níveis de sombreamento, no inverno. Revista Cultivando o Saber. 2012;8(3):294-301. doi: http://dx.doi.org/10.1818/sap.v15i1.10360.

Dickson A, Leaf AL, Hosner JF. Quality appraisal of white spruce and white pine seedling stock in 
nurseries. Forest Chronicle. 1960;36(1):10-13. doi: https://doi.org/10.5558/tfc36010-1.

DUKE NC. Mangrove Floristics and Biogeography Revisited: further deductions from Biodiversity hot spots, ancestral discontinuities, and common evolutionary processes. In: Rivera-Monroy VH, Lee SY, Kristensen E, Twilley RR (eds.). Mangrove Ecosystems: a global biogeographic perspective. Springer, 2017;38:17-53. doi: 10.1007/978-3-31962206-4

Dutra TR, Massad MD, Santana RC. Parâmetros fisiológicos de mudas de copaíba sob diferentes substratos e condições de sombreamento. Ciência Rural. 2012;42(7):1212-1218. doi: http://dx.doi. org/10.1590/S0103-84782012005000048.

Fundação Cearense de Meteorologia e Recursos Hídricos - FUNCEME. Índice de aridez para o Estado do Ceará. [cited 2017 june 17]. Available: http://www.funceme.br/index.php/areas/17-mapastem $\% \mathrm{C} 3 \% \mathrm{~A} 1$ ticos $/ 542-\% \mathrm{C} 3 \% \mathrm{ADndice}-d e-a r i d e z-$ para-o-cear $\% \mathrm{C} 3 \% \mathrm{~A} 1$

Krauss KW, Lovelock CE, Mckee KL, LópezHoffman L, Ewe SML, Sousa WP. Environmental drivers in mangrove establishment and early development: a review. Aquatic Botany. 2008;89(2):105-127.

King DA. Influence of light level on the growth and morphology of saplings in a panamanian forest. American Journal of Botany. 1994;81(8):948-957. doi: http://dx.doi.org/10.2307/2445287.

Lee SY, Primavera JH, Dahdouh-Guebas F, Mckee $\mathrm{K}$, Bosire JO, Cannicci S, et al. Ecological role and services of tropical mangrove ecosystems: a reassessment. Global Ecology and Biogeography. 2014;23(7):726-743. doi: https://doi.org/10.1111/ geb. 12155 .

Lima Junior JC, Arraes FDD, Oliveira JB, Nascimento FAL, Macêdo KG. Parametrização da equação de Hargreaves e Samani para estimativa da evapotranspiração de referência no Estado do Ceará, Brasil. Revista Ciência Agronômica. 2016;47(3):447454. doi: http://dx.doi.org/10.5935/18066690.20160054 .

Lunz AMP. Crescimento e produtividade do cafeeiro sombreado e a pleno sol. [tese]. Piracicaba (SP):
Universidade de São Paulo - Escola Superior de Agricultura "Luiz Queiroz"; 2006.

Maciel MNM, Watzlawick LF, Schoeninger ER, Yamaji FM. Efeito da radiação solar na dinâmica de uma floresta. Revista Ciências Exatas e Naturais. 2002;4(1):101-114.

Maia RC, Rosa Filho JS, Rocha-Barreira CA, Matthews-Cascon H, Santos ES, David HN, et al. Benthic Estuarine Assemblages of the Northeastern Brazil Marine Ecoregion. In: Lana P, Bernardino, A (eds). Brazilian Marine Biodiversity. Springer, Cham; 2018. p.75-94. ISBN 978-3-319-77778-8.

Morandi PS, Marimon-Junior BH, Santos CO, Oliveira B, Reis SMA, Silva LS, et al. Germinação e Desenvolvimento Inicial de Calophyllum brasiliensis Camb. em Diferentes Níveis de Sombreamento. Anais da $2^{\circ}$ Jornada Científica da Unemat. 2009; Universidade do Estado de Mato Grosso. Barra do Burgues (MT); UNEMAT; 2009. p. 1-4.

Oliveira LEM. Temas em fisiologia vegetal: desenvolvimento de plântulas. Setor Fisiologia Vegetal do Departamento de Biologia da Universidade Federal de Lavras. [cited 2017 December 10]. Available: http://www.ledson.ufla.br/ metabolismo-da-germinacao/etapas-da-germinacao/ desenvolvimento-de-plantulas/.

Oliveira AKM, Perez SCJGA. Crescimento inicial de Tabebuia aurea sob três intensidades luminosas. Revista Ciência Florestal. 2012;22(2):263-273. doi: http://dx.doi.org/10.5902/198050985733.

Paiva LC, Guimarães RJ, Souza CAS. Influência de diferentes níveis de sombreamento sobre o crescimento de mudas de cafeeiro (Coffea arabica L.). Ciênc. agrotec. 2003;27(1):134-140. doi: http:// dx.doi.org/10.1590/S1413-70542003000100016.

Pereira FHF, Sá FVS, Puiatti M, Finger FL, Cecon PR. Crescimento de planta, partição de assimilados e produção de frutos de melão amarelo sombreado por diferentes malhas. Ciência Rural. 2015;45(10):17741781. doi: http://dx.doi.org/10.1590/0103$8478 \mathrm{cr} 20141134$.

Pereira FV, Foletto F, Moreira TM, Gomes JML, Bernini E. Estrutura da vegetação em duas áreas com diferentes históricos de antropização no manguezal de Anchieta, ES. Boletim do Laboratório de 
Hidrobiologia. 2009;22(1):1-8.

Pérez A, Machado W, Gutierrez D, Stokes D, Sanders L, Smoak JM, et al. Changes in organic carbon accumulation driven by mangrove expansion and deforestation in a New Zealand estuary. Estuarine, Coastal and Shelf Science. 2017;192:108116. doi: https://doi.org/10.1016/j.ecss.2017.05.009.

Querino CAS, Moura MAL, Querino JKAS. Impacto do desmatamento de uma área de mangue no albedo superficial. Revista Brasileira de Meteorologia. 2013;28(4):401-408. doi: http://dx.doi.org/10.1590/ s0102-77862013000400006.

Rezende AJ, Oliveira CP, Gonçalves FOM. Efeito de luminosidade no desenvolvimento inicial de mudas de Lonchocarpus subglaucescens. [cited 2017 September 22]. Available: http:// fait.revista.inf.br/imagens_arquivos/arquivos destaque/6wTEbVwbPXfBfOp_2014-4-16-16-16-16.pdf.

Rezende CE, Kahn JR, Passareli L, Vásquez WF. An economic valuation of mangrove restoration in Brazil. Ecological Economics. 2015:120:296-302. doi: https://doi.org/10.1016/j.ecolecon.2015.10.019

Saenger P. Mangrove Ecology, Silviculture and Conservaton. Dordrecht: Springer Science e Business Media; 2002. 351 p. doi: 10.1007/978-94015-9962-7.
Santos TO, Andrade KVS, Santos HVS, Castaneda DAFG, Santana MBS, Holanda FSR, et al. Caracterização estrutural de bosques de mangue: estuário do São Francisco. Scientia Plena. 2012;8(4):1-7.

Silva NR, Maia RC. Avaliação do tamanho e peso de propágulos das espécies pioneiras de mangue na formação de plântulas para a recuperação de manguezais. Gaia Scientia. 2018;12(3):117128. doi: https://doi.org/10.22478/ufpb.1981$1268.2018 \mathrm{v} 12 \mathrm{n} 3.39306$.

Silva JPG, Rocha AP, Beltrão MRM, Oliveira ATS, Silva EPS, Passos MAA. Germinação de sementes de Laguncularia racemosa (L.). (mangue branco) coletadas com diferentes procedimentos. Universidade Federal de Pernambuco. [cited 2017 September 26]. Available: http://www.eventosufrpe. com.br/jepex2009/cd/resumos/r1413-1.pdf

Tomlinson PB. The botany of mangroves. 2. ed. University Press Cambridge; 2016. 418 p. doi: https://doi.org/10.1017/CBO9781139946575.

Vale CC, Schaeffer-Novelli Y. A Zona Costeira do Brasil e os manguezais. In: Atlas dos Manguezais do Brasil. Instituto Chico Mendes de Conservação da Biodiversidade. Brasília, 2018. 176 p. ISBN 97885-61842-75-8. Available in: http://www.icmbio. gov.br/portal/images/stories/manguezais/atlas_dos_ manguezais_do_brasil.pdf.

\section{ERRATA}

No artigo "EVALUATION OF THE GROWTH AND SURVIVAL OF MANGROVE SEEDLINGS UNDER DIFFERENT LIGHT INTENSITIES: SIMULATING THE EFFECT OF MANGROVE DEFORESTATION.”, publicado no número 3, volume 43, da Revista Árvore, onde se lê:

Neilson Rocha da Silva ${ }^{2 *}$, Rafaela Camargo $\mathrm{Maiab}^{3}$

L eia- s e:

Neilson Rocha da Silva ${ }^{2 *}$, Rafaela Camargo Maia $^{3}$ 